Agro-Science Journal of Tropical Agriculture, Food, Environment and Extension Volume 18 Number 1 (January 2019) pp. 7-15

ISSN 1119-7455

\title{
DIFFERENTIAL SPECIATION AND AVAILABILITY OF COPPER IN SOILS DERIVED FROM DIFFERENT PARENT MATERIALS IN IMO STATE, SOUTHEASTERN NIGERIA
}

\author{
"Okoli N.H., Uzoho B.U., Ihem E.E. and Okon M.A.
}

Department of Soil Science \& Technology

Federal University of Technology, P.M.B. 1526, Owerri, Imo State

Corresponding author's email: henrynek34@gmail.com,nnaemeka.okoli@futo.edu.ng

\begin{abstract}
Effective and efficient management of copper (Cu) in soils for optimum crop production and environmental conservation depends on proper knowledge of the various copper forms and fractions in soils as well as parent material. The distribution of forms of $\mathrm{Cu}$ in soils of different parent materials (coastal plain sands, alluvium, false-bedded sandstones and Imo clay shale) in Imo State, Southeastern Nigeria was evaluated using sequential extraction procedure, comprising of six fractions; water soluble (WS), exchangeable (EX), specifically sorbed/CO $\mathrm{O}_{3}$ bound (SSC), Fe-Mn bound (Fe-Mn), organic matter bound (OMB) and residual bound (RE) fractions. Soil was sampled at 0-15, 15-30, 30-45, 45-60 and 60-75 cm depths from each soil. Data obtained were subjected to analysis of variance and means separation was done by the procedure of Least Significant Difference at 5\% probability level. Correlation analysis of the various Cu forms and some soil properties was also carried out. Results showed that the water soluble, specifically sorbed/carbonate bound, Fe-Mn bound, organic matter bound (OMB) and residual bound (RE Cu fractions differed significantly among the soils of the different parent materials. The Fe-Mn bound copper was the dominant fraction in most of the soils, contributing 41.53-46.63\% to the total $\mathrm{Cu}$, being highest in the alluvial soil $\left(6.389 \mathrm{mg} \mathrm{kg}^{-1}\right)$ and lowest in the Imo clay shale soil $\left(2.231 \mathrm{mg} \mathrm{kg}^{-1}\right)$. Moderate concentrations of available $\mathrm{Cu}\left(0.694-1.456 \mathrm{mg} \mathrm{kg}^{-1}\right)$ were observed and significant differences were observed among the soils. Correlations among the different $\mathrm{Cu}$ forms (WS vs $\mathrm{EX} r-0.48 ; \mathrm{EX}$ vs $\mathrm{Fe}-\mathrm{Mn} r-0.46$ ) and some soil properties (OM vs Fe-Mn r-0.86; Ca vs RE r-0.59; Clay Vs Fe-Mn r-0.53) were determined.
\end{abstract}

Key words: copper fractions, copper availability, parent materials, soil properties, southeastern Nigeria

\section{INTRODUCTION}

Copper is a micronutrient element which acts as a medium for electron transport in enzyme systems responsible for oxidation-reduction processes in photosynthesis (Brady and Weil, 2010). Halvin et al. (2012) noted that copper is necessary in plants for photosynthesis, respiration, lignin formation in cell walls, carbohydrate metabolism and lipid metabolism. Copper is immobile in plant system, hence its deficiency in plants first appears in younger leaves, showing chlorosis, withering and usually distortion of terminal leaves and subsequently premature death of the apex resulting in the production of several auxiliary buds (Singh, 2011). Copper present in soils appears in several forms that are partitioned between the solution and the solid phases. Its bioavailability and phytotoxicity are closely related to its distribution in the different chemical forms (Lagomarsino et al.,
2010). These chemical forms include soluble and exchangeable form, organic matter bound, carbonate bound, Mn-oxide, amorphous Fe-oxide, crystalline $\mathrm{Fe}$-oxide associated metal forms, and residual fraction or metal ions fixed to silicate structures (Fathi et al., 2014). The water soluble and exchangeable forms are considered readily mobile and available to plants; while metal incorporated into crystalline lattices of clays appear relatively inactive. The other forms-precipitated as carbonate, occluded in $\mathrm{Fe}, \mathrm{Mn}$ and $\mathrm{Al}$ oxides or complexed with organic matter could be considered relatively active or firmly bound, depending upon the actual combination of physical and chemical properties of soil (Kabata-Pendias, 2011). Parent materials tend to govern the initial status of copper fractions in soils (Melo, 2006). It has been reported that soils derived from alluvium are richer in 
organic matter bound copper than soils derived from coastal plain sands (Ideriah et al., 2013; Oviasogie et al., 2011) Also, higher concentration of water soluble copper has been observed in soils derived from sandstones relative to soils derived from highly weathered quaternary red earths ( $\mathrm{Yu}$ et al., 2004). An evaluation of total metal levels following a strong acid digestion of soil may be useful as a general indicator of contamination, but it provides little indication of metal's bioavailability, mobility, and reactivity in soils (Baltrenaite et al., 2009). Due to the significant impact of parent material on soil chemical properties, the knowledge of influence of parent materials on chemical speciation of metals in the soil environment is important. This will provide land managers managing soils derived from different parent materials with useful guide necessary for proper management of land resources. Thus, there is the need to evaluate the chemical fractions of metals in soils from different parent materials. Although there have been a lot of studies on chemical fractionation of copper in soils, there is dearth of information on the influence of parent materials on the chemical fractions of copper in the soils of Imo State, Southeastern Nigeria. Therefore, the objective of this study was to examine the chemical fractions and availability of copper in soils from different parent materials in Imo State, Southeastern Nigeria.

\section{MATERIALS AND METHODS Study Area}

The study was conducted in four different locations in Imo State, Southeastern Nigeria. The soils were derived from four different parent materials namely coastal plain sands, alluvium, Imo clay shale and false bedded sandstones (Orajaka, 1975). The study locations were Ihiagwa (Coastal plain sands) located between Latitudes $5^{\circ} 21^{\prime}$ and $5^{\circ} 27^{\prime} \mathrm{N}$ and longitudes $7^{\circ} 02^{\prime}$ and $7^{\circ} 15^{\prime} \mathrm{E}$, Egwe (Alluvium) located between Latitudes $5^{\circ} 42^{\prime}$ and $5^{\circ} 46^{\prime} \mathrm{N}$ and Longitudes $6^{\circ} 47^{\prime}$ and 6 $49^{\prime} \mathrm{E}$, Amauro (Imo clay shale) located between latitudes $5^{\circ} 48^{\prime}$ and $5^{\circ} 53^{\prime} \mathrm{N}$ and Longitudes $7^{\circ} 20^{\prime}$ and $7^{\circ} 25^{\prime} \mathrm{E}$ and Mbato (Falsebedded sandstones) located between Latitudes $5^{\circ} 55^{\prime}$ and $5^{\circ} 58^{\prime} \mathrm{N}$ and Longitudes $7^{\circ} 02^{\prime}$ and $7^{\circ} 08^{\prime} \mathrm{E}$. Imo State lies between Latitudes $4^{\circ} 40^{\prime}$ and $8^{\circ} 15^{\prime} \mathrm{N}$ and Longitudes $6^{\circ} 40^{\prime}$ and $8^{\circ} 15^{\prime}$ E. (Federal Department of Agricultural Land Resources, 1985) and it is within the humid tropics. Temperatures are high and change slightly during the year. Mean daily temperature is about $27^{\circ} \mathrm{C}$. The average annual rainfall is about $2400 \mathrm{~mm}$ and there is a distinct dry season of about 3 months usually from December-February (Okoli et al., 2016). The vegetation is characterized by multiple tree species such as oil bean tree (Pentaclethra macrophyllum), oil palm tree (Elaeis guineensis), mango
(Mangifera indica), etc. (Onweremadu et al., 2007b, Onweremadu and Peter, 2016). Agriculture and cottage industries are the major socioeconomic activities in Imo State. Crops mostly cultivated in the study area include yam (Dioscorea spp), cassava (Manihot spp), oil palm (Elaies guineensis) and maize (Zea mays) while cottage industries are Cassava processing, Oil palm processing, block molding, etc.

\section{Soil Sampling and Laboratory Analyses}

A profile pit was dug at each location, guided by the geological map of the study area. Triplicate samples were collected from 0-15, 15-30, 30-45, $45-60$ and $60-75 \mathrm{~cm}$ depths from each profile pit. The soil samples were air-dried, sieved through a 2-mm sieve and subjected to laboratory analyses. The analyses conducted included particle size distribution (Gee and Or, 2002) and $\mathrm{pH}$ (1: 2.5 soil/water) using glass electrode $\mathrm{pH}$ meter (Thomas, 1996). Exchangeable cations $\left(\mathrm{Ca}^{2+}\right.$, $\mathrm{Mg}^{2+}, \mathrm{K}^{+}, \mathrm{Na}^{+}$) were extracted with $\mathrm{NH}_{4} \mathrm{OAc}$ buffered at $\mathrm{pH} 7.0$ (Thomas, 1982). The exchangeable $\mathrm{K}^{+}$and $\mathrm{Na}^{+}$were determined using the flame photometer while exchangeable $\mathrm{Ca}^{2+}$ and $\mathrm{Mg}^{2+}$ were determined using the ICE 3300 atomic absorption spectrophotometer. Exchangeable acidity $\left(\mathrm{Al}^{3+}\right.$ and $\left.\mathrm{H}^{+}\right)$was extracted with $1 \mathrm{~N} \mathrm{KCl}$ (Thomas, 1982) and determined by titrating with $0.5 \mathrm{~N} \mathrm{NaOH}$, using phenolphthalin as an indicator. Effective cation exchange capacity (ECEC) was obtained by summation of basic and acidic cations. Organic matter content of the soils was determined by the wet oxidation method (Nelson and Sommers, 1982) while available $\mathrm{P}$ was determined using Bray II solution (Olsen and Sommers, 1982).

\section{Copper Sequential Fractionation Procedures}

Water soluble, exchangeable, specifically sorbed/carbonate bound, Fe-Mn oxide bound, organic matter bound and residual bound $\mathrm{Cu}$ fractions were determined using the sequential extraction procedure described by Salbu et al. (1998). The procedure is outlined as follows:

\section{Water Soluble Fraction (F1):}

Two grams of soil sample were weighed into a 50$\mathrm{mL}$ polycarbonate centrifuge tube and extracted using $20 \mathrm{~mL}$ of de-ionised water for $1 \mathrm{~h}$ at $20^{\circ} \mathrm{C}$ on a rolling table.

\section{Exchangeable Fraction (F2):}

The residue obtained from water soluble extraction was washed with $10 \mathrm{~mL}$ de-ionised water and the supernatant discarded. The residue was transferred into a $50 \mathrm{~mL}$ polycarbonate centrifuge tube and extracted with $20 \mathrm{~mL}$ of $1 \mathrm{M} \mathrm{NH} \mathrm{NH}_{4} \mathrm{OAc}$ solution buffered at $\mathrm{pH} 7$ for $2 \mathrm{~h}$. 


\begin{abstract}
Specifically Sorbed and Carbonate Bound Fraction (F3):

The residue obtained from the extraction of exchangeable form was washed with $10 \mathrm{~mL}$ deionised water and the supernatant discarded. The residue was transferred into a $50-\mathrm{mL}$ polycarbonate tube and extracted with $20 \mathrm{~mL}$ of $1 \mathrm{M} \mathrm{N} \mathrm{NH}_{4} \mathrm{OAc}$ solution buffered at $\mathrm{pH} 5$ for $2 \mathrm{~h}$.
\end{abstract}

\section{Fe-Mn Oxide Bound Fraction (F4):}

The residue obtained from the extraction of specifically sorbed and carbonate bound form was washed with $10 \mathrm{~mL}$ de-ionised water and the supernatant discarded. The residue was transferred into a $50-\mathrm{mL}$ polycarbonate tube and extracted with $20 \mathrm{~mL}$ of $0.04 \mathrm{M} \mathrm{NH}_{2} \mathrm{OH} . \mathrm{HCl}$ in $25 \% \mathrm{HOAc}$ for 6 $\mathrm{h}$ in a water bath at $60^{\circ} \mathrm{C}$.

\section{Organic Matter Bound Fraction (F5):}

In this procedure, residue obtained from the extraction of Fe-Mn oxide bound form was washed with $10 \mathrm{~mL}$ deionised water and transferred into a $50-\mathrm{mL}$ polycarbonate tube and extracted with 15 $\mathrm{mL}$ of $30 \% \mathrm{H}_{2} \mathrm{O}_{2}$ at $\mathrm{pH} 2$ ( adjusted with $\mathrm{HNO}_{3}$ ) for $5.5 \mathrm{~h}$ in a water bath at $80^{\circ} \mathrm{C}$. The content was allowed to cool and $5 \mathrm{~mL}$ of $3.2 \mathrm{M} \mathrm{NH}_{4} \mathrm{OAc}$ in $20 \% \mathrm{HNO}_{3}$ was added and diluted to $20 \mathrm{~mL}$ with deionised water.

\section{Residual Fraction (F6):}

In this method, $1 \mathrm{~g}$ of the residue obtained from the extraction of organic matter bound form was dried after which it was digested in a conical flask with $10 \mathrm{~mL}$ of $7 \mathrm{M} \mathrm{HNO}_{3}$ on a hot plate for $6 \mathrm{~h}$. After evaporation, $1 \mathrm{~mL}$ of $2 \mathrm{M} \mathrm{HNO}_{3}$ was added and the residue dissolved. Thereafter, it was diluted using $10 \mathrm{~mL}$ de-ionised water. After each successive extraction, the mixture of soil sample and extractant was centrifuged at $1000 \mathrm{rpm}$ for 30 min and the supernatant decanted into polyethylene bottles, acidified to $\mathrm{pH}<2$ and stored for analysis. The various chemical fractions of $\mathrm{Cu}$ were determined using ICE 3300 atomic absorption spectrophotometer at $324.8 \mathrm{~nm}$ wavelength.

\section{Available and Total Copper Determination}

Available copper was calculated as sum of water soluble (F1) and exchangeable (F2) fractions $(\mathrm{F} 1+\mathrm{F} 2)$ while total copper was calculated as sum of all the fractions $(\mathrm{F} 1+\mathrm{F} 2+\mathrm{F} 3+\mathrm{F} 4+\mathrm{F} 5+\mathrm{F} 6)$ determined (Ramzan et al., 2014).

\section{Statistical Analysis}

Data obtained from selected phyisco-chemical properties and copper fractions determined were subjected to Analysis of Variance (ANOVA) and means were separated using Least Significant Differences (LSD) at 5\% level of Probability. Correlations between selected soil properties and copper forms and amongst copper fractions were determined. All statistical analyses were done using GenStat statistical package described by Buysse $e t$ al. (2004)

\section{RESULTS AND DISCUSSION \\ Physico-chemical Properties of the Soils of Different Parent Materials}

The results of the physico-chemical properties of the soils studied are presented in Table 1. Particle size distribution varied significantly $(\mathrm{p}<0.05)$ among the soils of the different parent materials. Three textural classes comprising sand, loamy sand and sandy loam were observed in the soils of the coastal plain sands. For the alluvial soils, the texture was sand all through the profile. The texture of the false-bedded sand-stone soils varied from sandy loam to sandy clay loam while the variation was from clay loam to clay in the soils derived from Imo clay shale. The results showed decreasing sand fraction with depth whereas clay fraction increased with depth. The increasing clay content with depth could be attributed to the illuviation process that has taken place, leading to accumulation of clay in the lower horizons (Esu, 2005). The high sand fraction observed in the soils derived from coastal plain sands could be due to the sandy nature of the parent material (Onweremadu et al., 2007a). Similarly, significant $(\mathrm{p}<0.05)$ higher clay fraction observed in the soils of Imo clay shale could be attributed to the clayey nature of the parent material (Anenyeonwu, 2016). The high values of sand fraction in soils derived from alluvium were similar to the report of Onweremadu et al. (2007b) for soils of the same study area derived from alluvium. These authors attributed the results to the presence of old deltaic, lacustrine and fluvial deposits in the area.

The soils derived from the Imo clay shale and the surface soil derived from the false-bedded sandstones contained moderate amounts of organic matter. The organic matter content of the other soils was low (FAO, 2004) and varied significantly $(\mathrm{p}<0.05)$. Similar results were reported for some soils of the same area by Uzoho et al. (2014). The low organic matter content of most of the soils was attributed to high temperature and rainfall in the area which encourages rapid mineralization, erosion and leaching of organic matter (Nwagbara and Ibe, 2015). The soils generally contained very low to low amounts exchangeable calcium (FAO, 2004). Similar results were reported for some soils in the area derived from coastal plain sands and alluvium by Onweremadu et al. (2011). They attributed the observation to the sandy texture and the leaching prone characteristics of the soils. Acidity $(\mathrm{pH})$ differed significantly $(\mathrm{p}<0.05)$ among the soils, ranging from 4.28 to 5.63 in coastal plain sands soils, 5.31 to 5.62 in alluvial soils, 5.12 to 5.41 in false bedded sandstone soils and 5.55 to 5.98 in Imo clay shale soils. These values varied from extremely acidic to moderately acidic (FAO, 2004). 
The generally low $\mathrm{pH}$ of the soils could be due to the high amounts of rainfall in the study area and the associated leaching out of the basic cations $\left(\mathrm{Ca}^{2+}, \mathrm{K}^{+}, \mathrm{Na}^{+}\right.$and $\left.\mathrm{Mg}^{2+}\right)$, leading to the dominance of acidic cations $\left(\mathrm{Al}^{3+}, \mathrm{H}^{+}\right)$on the exchange complex of the soils. Similar pH results have been reported by Ahukaemere et al. (2016) for some soils of southeastern Nigeria. Also, differences in the $\mathrm{pH}$ of some soils from southeastern Nigeria derived from different parent materials had been reported (Obalum and Chibuike, 2017). The soils contained very low levels of available $\mathrm{P}\left(0.23-3.36 \mathrm{mg} \mathrm{kg}^{-1}\right)$ which were far lower than the critical limit of 10 $\mathrm{mg} \mathrm{kg}{ }^{-1}$ recommended by Esu (1999) for arable crop production. However, the soils derived from the alluvium contained relatively higher levels of available $\mathrm{P}$. The low levels of available $\mathrm{P}$ in the soils could be due to fixation by sesquioxides in the low pH soil environments (Havlin et al., 2012). The exchangeable properties are presented in Table 1. Comparatively, the Imo clay shale soils had the highest ECEC of $5.28 \mathrm{cmol}_{\mathrm{c}} \mathrm{kg}^{-1}$ which may be attributed to its higher clay content while the alluvial soils had the lowest value $4.16 \mathrm{cmol}_{\mathrm{c}} \mathrm{kg}^{-1}$.
However, these values are low when compared with the critical limit of $6 \mathrm{cmol}_{\mathrm{c}} \mathrm{kg}^{-1}$ recommended by Esu (1991) for arable crop production. The ECEC of soil is a reflection of its metal retention capacity and is an important parameter in the prediction of metal retention, movement and extractability (Udom et al., 2004: Rieuwerts et al., 2005). The low ECEC of the soils could be attributed to parent materials, climate and land use interactions (Onweremadu et al., 2011).

Fractions and Distribution of Copper in the Soils The results of the distribution of the copper forms in the soils are presented in Table 2. The concentration of water soluble copper was low in the soils and differed significantly $(\mathrm{p}<0.05)$ among the soils with the highest mean value of $0.795 \mathrm{mg} \mathrm{kg}^{-1}$ equivalent to $12.93 \%$ of total copper recorded in the soils of the false bedded sandstones and the lowest mean value of $0.269 \mathrm{mg} \mathrm{kg}^{-1}$ equivalent to $3.85 \%$ of total copper observed in the soils of the coastal plain sands. Apart from the False-bedded sandstones soils, the water-soluble $\mathrm{Cu}$ form was the smallest in the soils.

Table 1: Physico-chemical properties of the sampled soils

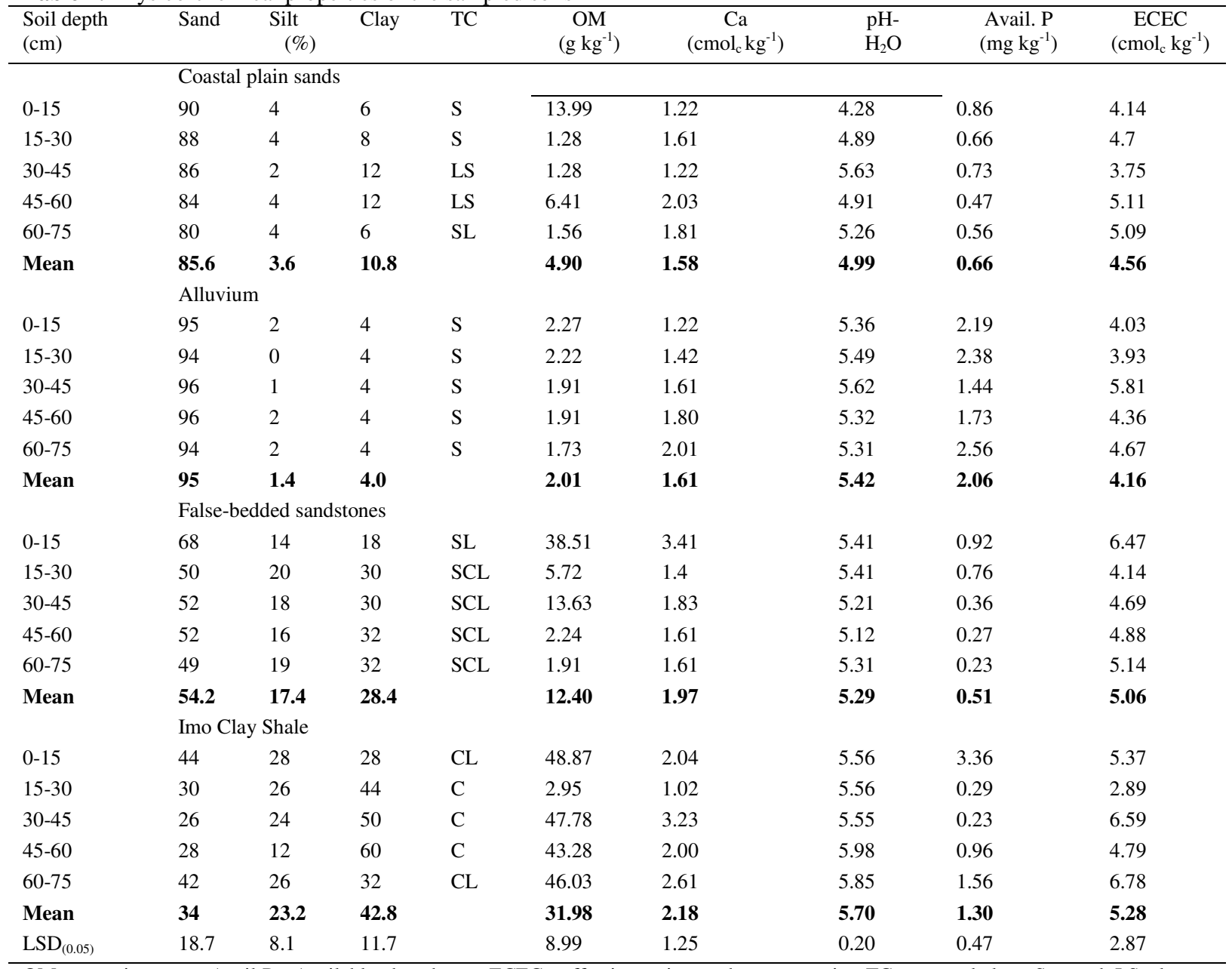

OM - organic matter, Avail P - Available phosphorus, ECEC - effective cation exchange capacity, TC - textural class, S - sand, LS - loamy sand, SL - sandy loam, SCL - sandy clay loam, CL - clay loam, C - clay 
The low concentration of water soluble copper when compared with the other fractions in the soils could be due to losses from leaching and plant uptake, since this represents the fraction that is most bioavailable and mobile in soils (Filgueiras et al., 2002) or as a result of poor extractive strength of water (Mbila et al., 2001). Low level of water soluble fraction of metals is natural for forest and unpolluted soils. Kabata-Pendias et al. (2011) noted that copper in soil solution ranges from 0.0005 to $0.135 \mathrm{mgkg}^{-1}$, depending on the techniques used and on soil types. The results obtained in this study were higher than the range reported by Kabata-Pendias et al. (2011) for soil solutions. Probably, the low $\mathrm{pH}$ of the soils might have contributed to the high solubility of copper in the soil solutions (Havlin et al., 2012). It may as well be due to low organic matter content of the soils $(<50 \mathrm{~g} / \mathrm{kg})$ which agreed with the reports of Havlin et al. (2012) who observed that copper is more strongly bound to organic matter than any other micronutrient, an indication that decreasing OM in soils, increases copper solubility. The values obtained for soils derived from coastal plain sands were similar to results obtained by Koka et al. (2011) who reported a mean value of $0.265 \mathrm{mg} \mathrm{kg}^{-1}$ in the topsoils of some cocoa growing areas of the Central Region of Ghana. The values obtained in the soils derived from false bedded sandstones were similar to those reported for some Inceptisols derived from sandstones by Yu et al. (2004).

Furthermore, with the exception of the soils derived from false bedded sandstones, other soils showed highest accumulation of water soluble $\mathrm{Cu}$ at the surface horizon perhaps due to anthropogenic activities (Kabata-Pendias and Pendias, 2001). The water soluble $\mathrm{Cu}$ content of the soils was in the order; false-bedded sandstones > Imo clay shale > alluvium > coastal plain sands. Apart from soils derived from false bedded sandstones, exchangeable copper fraction in the soil profiles was higher than the water soluble fraction in the soils, but there was no significance difference ( $\mathrm{p}<$ 0.05 ) among the different soils. The results showed that the highest mean value $0.661 \mathrm{mg} \mathrm{kg}^{-1}$ was observed in the soils of false-bedded sandstones whereas soils of alluvium had the least mean of $0.354 \mathrm{mg} \mathrm{kg}^{-1}$. Apart from the water-soluble, organic matter bound and residual fractions, the exchangeable $\mathrm{Cu}$ fraction was the smallest of the total $\mathrm{Cu}$ content of the soils and constituted about $7.09,2.58,10.75$ and $11.22 \%$ of total copper concentration in the soils derived from coastal plain sands, alluvium, false bedded sandstones and Imo clay shale, respectively. The exchangeable copper levels were lower than the $20 \mathrm{mg} \mathrm{kg}^{-1}$ reported for some soils from a former vineyard of Torino, Italy (Lagomarsino et al., 2010) and the $20.08 \mathrm{mg} \mathrm{kg}^{-1}$ reported for some Inceptisols derived from sandstones (Yu et al., 2004). The low levels of exchangeable $\mathrm{Cu}$ in the soils may be due to the low organic matter content of the soils which may have reduced the exchange sites (Brady and Weil, 2010). In addition, the low $\mathrm{pH}$ of the soils may have reduced the number exchange sites (Havlin et al., 2012). The specifically sorbed/carbonate bound copper fraction was higher than water soluble and exchangeable copper fractions in the soils and varied significantly $(\mathrm{p}<$ 0.05) among the soils. However, the values were lower than the $\mathrm{Fe}-\mathrm{Mn}$ bound $\mathrm{Cu}$ fraction in the soils. The highest Mean value of $5.483 \mathrm{mg} \mathrm{kg}^{-1}$ equivalent to $40.02 \%$ of total copper was observed in the soils derived from alluvium whereas least mean value of $1.736 \mathrm{mg} \mathrm{kg}^{-1}$ equivalent to $28.24 \%$ of total copper was recorded in the soils derived from false-bedded sandstones (Table 2). The specifically sorbed/carbonate $\mathrm{Cu}$ content of the soils based on their parent materials was in a decreasing order of alluvium $>$ coastal plain sands $>$ Imo clay shale $>$ false bedded sandstones. The values obtained for the soils of the alluvium and falsebedded sandstones were similar to those the reported by Oviasogie et al. (2011) in the wetland (Alluvium) soils of the Niger Delta, Nigeria and those reported by $\mathrm{Yu}$ et al. (2004) for some Inceptisols derived from sandstones in China, respectively. The results further showed decreasing concentration of the specifically sorbed/carbonate with depth in the soil derived from the alluvium but the distribution in the other soils did not follow any well-defined pattern. The Fe-Mn bound copper fraction differed significantly $(\mathrm{p}<0.05)$ among the soils of different parent materials. The highest mean value of $6.389 \mathrm{mgkg}^{-}{ }^{1}$ equivalent to $46.63 \%$ of the total copper concentration was observed in the soils derived from alluvium while the lowest mean value of $2.231 \mathrm{mg} \mathrm{kg}^{-1}$ equivalent to $45.42 \%$ of the total Copper concentration was recorded in the soils derived from the Imo clay shale. A comparison with the other copper fractions showed that the Fe-Mn bound copper was the most dominant fraction which is consistent with the reports of Kabat-Pendias and Pendias (2001) and that of Oviasogie et al. (2011) for alluvial soils of the Niger Delta, Nigeria. Kabata-Pendias (2011) had reported that the greatest amounts of adsorbed $\mathrm{Cu}$ have always been found in $\mathrm{Fe}$ and $\mathrm{Mn}$ oxides (hematite, goethite, birnessite), amorphous $\mathrm{Fe}$ and Al hydroxides, and clays (Kabata-Pendias, 2011) which could be due to adsorption mechanism of copper onto metal oxides. Copper forms strong surface bonds with metal oxides such as $\mathrm{Cu}-\mathrm{O}-\mathrm{Al}$, $\mathrm{Cu}-\mathrm{O}-\mathrm{Mn}$ or $\mathrm{Cu}-\mathrm{O}-\mathrm{Fe}$ which do not break easily (Halvin et al., 2012). The organic matter bound copper fraction in the soils was very low and in many cases, particularly in soils derived from Imo clay shale, was not detectable. 
Table 2: Fractions and distribution of copper $\left(\mathrm{mg} \mathrm{kg}^{-1}\right)$ in the soils

\begin{tabular}{|c|c|c|c|c|c|c|c|c|}
\hline Depth (cm) & $\begin{array}{l}\begin{array}{l}\text { Water } \\
\text { Soluble } \\
\left(\mathrm{mg} \mathrm{kg}^{-1}\right)\end{array} \\
\end{array}$ & Exchangeable & Available & $\begin{array}{l}\text { Specifically } \\
\text { sorbed/CO }\end{array}$ & Fe-Mn bound & OM bound & $\begin{array}{l}\text { Residual } \\
\text { Bound }\end{array}$ & Total \\
\hline & \multicolumn{8}{|c|}{ Coastal plain sands } \\
\hline $0-15$ & 0.603 & 0.739 & 1.342 & 0.943 & 2.320 & ND & ND & 4.605 \\
\hline $15-30$ & 0.149 & 0.733 & 0.882 & 0.454 & 4.441 & 0.413 & ND & 6.190 \\
\hline $30-45$ & 0.138 & 0.112 & 0.250 & 5.931 & 3.144 & 0.543 & ND & 9.868 \\
\hline $45-60$ & 0.067 & 0.239 & 0.306 & 1.007 & 3.855 & ND & ND & 5.168 \\
\hline $60-75$ & 0.386 & 0.650 & 1.036 & 5.243 & 2.151 & 0.639 & ND & 9.069 \\
\hline Mean & 0.269 & 0.495 & 0.764 & 2.716 & 3.182 & 0.319 & ND & 6.980 \\
\hline$\%$ Total & $3.85 \%$ & $7.09 \%$ & $10.95 \%$ & $38.91 \%$ & $45.58 \%$ & $4.57 \%$ & & \\
\hline $\begin{array}{l}0-15 \\
15-30 \\
30-45 \\
45-60\end{array}$ & $\begin{array}{l}\text { Alluvium } \\
0.403 \\
0.342 \\
0.280 \\
0.272\end{array}$ & $\begin{array}{l}0.795 \\
0.001 \\
0.398 \\
0.283\end{array}$ & $\begin{array}{l}1.198 \\
0.343 \\
0.678 \\
0.555\end{array}$ & $\begin{array}{l}7.104 \\
6.153 \\
5.202 \\
4.569\end{array}$ & $\begin{array}{l}1.373 \\
5.201 \\
6.223 \\
8.103\end{array}$ & $\begin{array}{l}\text { ND } \\
0.611 \\
0.993 \\
0.331\end{array}$ & $\begin{array}{l}\text { ND } \\
\text { ND } \\
\text { ND } \\
\text { ND }\end{array}$ & $\begin{array}{l}10.873 \\
12.651 \\
13.774 \\
14.113\end{array}$ \\
\hline $60-75$ & 0.337 & 0.295 & 0.620 & 4.385 & 11.049 & 0.277 & ND & 16.963 \\
\hline Mean & 0.340 & 0.354 & 0.694 & 5.483 & 6.389 & 0.442 & ND & 13.702 \\
\hline$\%$ Total & $\begin{array}{l}2.48 \% \\
\text { False-bedd }\end{array}$ & \multicolumn{2}{|c|}{ False-bedded Sandstones } & $40.02 \%$ & $46.63 \%$ & & & \\
\hline $0-15$ & 0.365 & 0.663 & 1.028 & 1.476 & 7.604 & ND & 1.125 & 11.232 \\
\hline $15-30$ & 0.550 & 0.372 & 0.922 & 0.892 & 2.299 & ND & ND & 4.113 \\
\hline $30-45$ & 2.205 & 0.997 & 3.202 & 1.425 & 1.363 & ND & ND & 5.990 \\
\hline $45-60$ & 0.546 & 0.690 & 1.236 & 2.562 & 0.061 & ND & ND & 3.859 \\
\hline $60-75$ & 0.308 & 0.583 & 0.891 & 2.327 & 1.441 & 0.883 & ND & 5.542 \\
\hline Mean & 0.795 & 0.661 & 1.456 & 1.736 & 2.553 & 0.177 & 0.225 & 6.147 \\
\hline$\%$ Total & \multicolumn{7}{|c|}{ Imo Clay Shale } & \\
\hline $0-15$ & 0.360 & 0.507 & 0.867 & 1.632 & 4.260 & ND & ND & 6.759 \\
\hline $15-30$ & 0.310 & 0.426 & 0.736 & 0.477 & 1.947 & ND & ND & 3.160 \\
\hline $30-45$ & 0.354 & 0.490 & 0.844 & 0.490 & 2.713 & ND & ND & 4.047 \\
\hline $45-60$ & 0.175 & 0.885 & 1.060 & 2.001 & 0.582 & ND & ND & 3.643 \\
\hline $60-75$ & 0.631 & 0.448 & 1.079 & 4.217 & 1.655 & ND & ND & 6.951 \\
\hline Mean & 0.366 & 0.551 & 0.917 & 1.763 & 2.231 & ND & ND & 4.912 \\
\hline$\%$ Total & $7.45 \%$ & $11.22 \%$ & $18.67 \%$ & $35.89 \%$ & $45.42 \%$ & & & \\
\hline $\operatorname{LSD}_{(0.05)}$ & 0.159 & 0.313 & 0.229 & 1.200 & 1.266 & 0.122 & 0.075 & 2.414 \\
\hline
\end{tabular}

ND - not detected

Table 3: Simple linear correlation among copper fractions and between copper fractions and selected soil properties $(n=20)$

\begin{tabular}{|c|c|c|c|c|c|c|}
\hline & Exch. $\mathrm{Cu}$ & W-S Cu & $\begin{array}{l}\text { Specifically } \\
\text { sorbed/CO } / \mathrm{CO}_{3} \text { bound } \mathrm{Cu}\end{array}$ & $\begin{array}{l}\mathrm{Fe} / \mathrm{Mn} \text { bound } \\
\mathrm{Cu}\end{array}$ & $\begin{array}{l}\mathrm{OM} \\
\text { bound } \mathrm{Cu}\end{array}$ & $\begin{array}{l}\text { Residual } \\
\text { bound } \mathrm{Cu}\end{array}$ \\
\hline Exch. $\mathrm{Cu}$ & - & - & - & - & - & - \\
\hline $\mathrm{W}-\mathrm{S} \mathrm{Cu}$ & $0.48 *$ & - & - & - & - & - \\
\hline $\mathrm{Fe} / \mathrm{Mn}$ bound $\mathrm{Cu}$ & $-.46^{*}$ & -0.24 & 0.10 & - & - & - \\
\hline $\mathrm{OM}$ bound $\mathrm{Cu}$ & -0.41 & 0.25 & 0.43 & 0.21 & - & - \\
\hline Avail. P. & 0.16 & -0.14 & 0.38 & $0.46^{*}$ & -0.10 & -0.03 \\
\hline $\mathrm{Ca}$ & 0.06 & -0.12 & 0.22 & 0.31 & 0.24 & $-0.59 *$ \\
\hline Clay & 0.30 & 0.11 & $-0.49 *$ & $-0.55^{*}$ & -0.36 & -0.08 \\
\hline ECEC & 0.18 & 0.04 & -0.16 & 0.08 & -0.22 & -0.40 \\
\hline $\mathrm{OM}$ & 0.24 & 0.06 & -0.27 & $-0.86^{* *}$ & -0.41 & 0.35 \\
\hline $\mathrm{P}^{\mathrm{H}}\left(\mathrm{H}_{2} \mathrm{O}\right)$ & 0.23 & -0.13 & -0.30 & 0.03 & 0.06 & 0.04 \\
\hline
\end{tabular}

W-S- water soluble, Avail. P-available phosphorus, ECEC - effective cation exchange capacity, OM - organic matter,

*-Significant at $5 \%$ probability level, $* *$ - significant at $1 \%$ probability level

The mean values of organic matter bound copper fraction significantly $(\mathrm{p}<0.05)$ decreased in the order of alluvium $\left(0.442 \mathrm{mg} \mathrm{kg}^{-1}\right)>$ coastal plain sands $\left(0.319 \mathrm{mg} \mathrm{kg}^{-1}\right)>$ false bedded sandstones (0.177 $\left.\mathrm{mg} \mathrm{kg}^{-1}\right)>$ Imo clay shale (not detected). Halvin et al. (2012) observed that at $\leq 8 \%$ soil OM, both organic and mineral surfaces are involved in $\mathrm{Cu}$ adsorption, while at $>8 \% \mathrm{OM}$, binding of $\mathrm{Cu}$ takes place mostly on organic surfaces. Thus, it is possible that the low values observed in the soils could be due to their low organic matter contents $(<$ $5 \%)$. Apart from the $1.125 \mathrm{mg} \mathrm{kg}^{-1}$ residual $\mathrm{Cu}$ contained in the surface of the soil derived from the False-bedded sandstones, residual $\mathrm{Cu}$ was not detectable in the soils. The results were similar tothose of Oviasogie et al. (2011) in the wetland 
(Alluvium) soils of the Niger Delta, Nigeria but far below mean value of $30.03 \mathrm{mg} \mathrm{kg}^{-1}$ reported by Fathi et al. (2014) in some soils of Iran. The low level of residual bound $\mathrm{Cu}$ in the soils could be due to high weathering of $\mathrm{Cu}$-bound rocks and minerals and the transformation of other $\mathrm{Cu}$ forms. (KabataPendias, 2011). Generally, the concentrations of copper fractions differed in each of the soil profiles. The fractions decreased in the order; Coastal Plain Sands: F4 > F3 > F2 > F5 > F1 > F6 Alluvium: F4 > F3 > F5 > F2 > F1 > F6 False Bedded Sandstones: $\mathrm{F} 4>\mathrm{F} 3>\mathrm{F} 1>\mathrm{F} 2>\mathrm{F} 6>\mathrm{F} 5$ Imo Clay Shale: F4 > F3 > F2 > F1 > F5 - F6 This clearly shows the dominance of the Fe-Mn oxide bound $\mathrm{Cu}$ in the soils which is consistent with the report of Oviasogie et al. (2011) in the wetland (Alluvium) soils of the Niger Delta, Nigeria.

\section{Distribution of Available and Total Copper in the Soils}

There was significant $(p<0.05)$ difference in the distribution of available copper among the soils. The mean values ranged from $0.694 \mathrm{mg} \mathrm{kg}^{-1}$ to $1.456 \mathrm{mg} \mathrm{kg}^{-1}$. The values fell within the medium range (i.e., $0.2-2.0 \mathrm{mg} \mathrm{kg}^{-1}$ ) of fertility ratings of available copper for arable crop production recommended by Esu (1991), which indicated that plants growing in the area were not likely to suffer copper deficiency. Adiele et al. (2015) and Verma et al. (2005) also reported medium concentrations of available copper in some soils of coastal plain sands $\left(0.8 \mathrm{mg} \mathrm{kg}^{-1}\right)$ in the farm of National Root Crop Research Institute, Abia State, Southeastern Nigeria and the alluvial soils $\left(0.26-1.90 \mathrm{mg} \mathrm{kg}^{-1}\right)$ of Punjab, India, respectively. The available $\mathrm{Cu}$ levels obtained in the soils derived from False-bedded sandstones were higher than average value of 0.18 $\mathrm{mg} \mathrm{kg}{ }^{-1}$ obtained from some soils derived from sandstones in the Akko Local Government Area of Gombe State, Nigeria (Mustapha et al., 2011). This result could be due to the fact the soils derived from the False bedded sandstones had lower $\mathrm{pH}$ than those soils used by Mustapha et al. (2011). Havlin et al. (2012) have shown that low $\mathrm{pH}$ increases $\mathrm{Cu}$ availability in soils. The total copper concentration also differed significantly $(\mathrm{p}<0.05)$ among the soils. It was highest in the alluvial soil with a mean value of $13.702 \mathrm{mg} \mathrm{kg}^{-1}$ and lowest in soil derived from Imo clay shale with a mean value of $4.912 \mathrm{mg} \mathrm{kg}^{-1}$. Havlin et al. (2012) noted that total copper concentration in soils varies between $1-40 \mathrm{mg} \mathrm{kg}^{-1}$ with an average value of about $9 \mathrm{mg}$ $\mathrm{kg}^{-1}$ and it may be 1 to $2 \mathrm{mg} \mathrm{kg}^{-1}$ in deficient soils. Thus, apart from the alluvial soil, the soils used in this study could be considered as low in total $\mathrm{Cu}$. The source of total $\mathrm{Cu}$ contents of the soils is speculated to be of lithogenic and pedogenic origin since there is no history of anthropogenic activity in the area that could result to accumulation of $\mathrm{Cu}$ in the soils. Iwegbue (2011) and Iyaka and Kakulu
(2009) had also reported low concentrations of total $\mathrm{Cu}$ in the coastal plain sands soils of Southeastern Nigeria and the sandstones soils of Bida, north central Nigeria, respectively. Similarly, the values obtained in the alluvial soils were consistent with the report of Oviasogie et al. (2011) in the wetland (Alluvium) soils of the Niger Delta, Nigeria. Furthermore, the total $\mathrm{Cu}$ concentrations in the soils were below the maximum permissible agricultural soil concentration of $100 \mathrm{mg} \mathrm{kg}^{-1}$ recommended by Kabata-Pendias and Pendias (2001).

\section{Relationships among Copper Fractions and Between Copper Fractions and Selected Soil Properties}

Few significant correlations existed among copper forms and between copper forms and selected soil properties (Table 3). Exchangeable copper had significant positive correlation with water soluble $\mathrm{Cu}(\mathrm{r}=0.48)$. On the contrary, exchangeable $\mathrm{Cu}$ significantly $(\mathrm{p}<0.05)$ and negatively correlated with $\mathrm{Fe}-\mathrm{Mn}$ bound $\mathrm{Cu}(\mathrm{r}=-0.46)$. Available phosphorous had significant $(\mathrm{p}<0.05)$ positive correlation with $\mathrm{Fe}-\mathrm{Mn}$ bound $\mathrm{Cu}(\mathrm{r}=0.46)$ whereas $\mathrm{Ca}$ had a significant negative correlation with residual bound $\mathrm{Cu}(\mathrm{r}=-0.59)$. Furthermore, clay had significant $(\mathrm{p}<0.05)$ negative correlation with $\mathrm{Fe}-\mathrm{Mn}$ bound $\mathrm{Cu}(\mathrm{r}=-0.53)$ and specifically sorbed/carbonate bound copper $(\mathrm{r}=-0.49)$. Thus, increases in clay content would be associated with significant decreases in Fe-Mn bound and specifically sorbed/carbonate bound copper forms. Organic matter content of the soils had a highly significant negative $(\mathrm{p}<0.01)$ correlation with Fe$\mathrm{Mn}$ bound $\mathrm{Cu}(\mathrm{r}=-0.86)$ which implies that increases in organic matter content of the soils would be associated with decreases in $\mathrm{Fe}-\mathrm{Mn}$ bound $\mathrm{Cu}$ (Table 3 ).

\section{CONCLUSIONS}

The results of this study have shown that water soluble, specifically sorbed/carbonate bound, FeMn bound, organic matter bound and residual bound copper fractions differed significantly among the soils of the different parent materials investigated. The Fe-Mn bound was the dominant copper fraction in the soils whereas residual bound copper was not detectable in majority of the soils probably because of high weathering of most of the $\mathrm{Cu}$-bearing rocks and minerals in the study area. All the soils had moderate concentrations of available copper, although the levels were significantly different. Significant correlations were obtained between exchangeable and water soluble $\mathrm{Cu}$ forms, exchangeable and $\mathrm{Fe}-\mathrm{Mn}$ bound $\mathrm{Cu}$ forms, available $\mathrm{P}$ and $\mathrm{Fe}-\mathrm{Mn}$ bound $\mathrm{Cu}$, Clay and $\mathrm{Fe}-\mathrm{Mn}$ bound $\mathrm{Cu}, \mathrm{Ca}$ and residual bound $\mathrm{Cu}$, Clay and Specifically sorbed/carbonate bound $\mathrm{Cu}$ and between organic matter and $\mathrm{Fe}-\mathrm{Mn}$ bound $\mathrm{Cu}$. 


\section{REFERENCES}

Adiele J.G., Egesi C., Nwagu A.S., Kahya S.S. and Ano A.O. (2015). Available iron distribution in Nigerian soils - A review. J. Soil Sci. Environ. Mgt., 6 (4), 6871

Ahukaemere C.M., Onweremadu E.U., Ndukwu B.N. and Okoli N.H. (2016). Pedogenesis of two lithologically similar soils under vegetation of contrasting features in Ohaji, South-eastern Nigeria. Agro-Science, 15 (3), 34-40

Anenyeonwu A.U. (2016). Geotechnical Properties and Classification of Some Soils Formed on Two Lithologic Materials in Imo State, Nigeria. An MSc Thesis, Postgraduate School, Federal University of Technology, Owerri Nigeria. 102 pp

Baltrenaite E., Sereviciene V. and Paliulis D. (2009). Variation of carbon and metal concentration in soil amended with sewage sludge. Ekologija, 55, 1-8

Brady N.C. and Weil R.R. (2010). Elements of the Nature and Properties of Soils $\left(3^{\text {rd }}\right.$ ed) Prentice Hall, upper Saddle River, NJ

Buysse W., Stern R. and Coe R. (2004). Gen Stat Discovery Edition for Everyday Use. ICRAF Nirobi, Kenya. 114 pp

Eshett E.T., Omueti J.A. and Juo A.S. (1990). Physicochemical, morphological and clay Mineralogical properties of soils overlying basement complex rocks in Ogoja, Northern Cross River State of Nigeria. Soil Sci. Plant Nutr., 36 (2), 203-214

Esu I.E. (1991). Detailed Soil Survey of NIHORT Farm at Bunkure Kano State, Nigeria. Institute. Agric Res., Zaria. $72 \mathrm{pp}$.

Esu I.E. (1999). Fundamentals of Pedology. StirlingHordan Publication (Nig.) Ltd. Ibadan. pp. 101

Esu I.E. (2005). Characterization Classification and Management Problems of the Major Soil Order in Nigeria. The 26th Inaugural Lecture of the University of Calabar, Nigeria, 66 pp.

FAO (Food and Agricultural Organization) (2004). A Provisional Methodology for Land Degradation Assessment. Food and Agricultural Organization, Rome

Fathi H., Aryanpour H., Fathi H. and Moradi H. (2014). Distribution of zinc and copper fractions in acid and alkaline (highly calcareous) soils of Iran. Sky Journal of Soil Science and Environmental Management, 3 (1), 6-13

Federal Department of Agricultural Land Resources (1985). The Reconnaissance Soil Survey of Imo State, Nigeria (1:250,000). Soils Report. 133 pp.

Filgueiras A.V., Lavilla I. and Bendicho C. (2002). Chemical sequential extraction in environmental solid samples. J. Environ. Monit., 4, 823-857

Gee G.W. and Or D. (2002). Particle size analysis. In: Dane J.H. and Topp G.C. (Eds.), Methods of Soil Analysis, Physical methods, Part 4. Soil Sci. Soc. Amer. Book series 5, ASA and SSSA, Madison, Wisconsin. Pp. 255-293

Havlin J.L., Beaton J.D., Tisdale S.L. and Nelson W.L. (2012). Soil Fertility and Fertilizers. An Introduction to Nutrient Management $\left(7^{\text {th }}\right.$ ed.). PHI Private Limited, New Delhi-110001. Pp. 513

Ideriah T.J.K., Ikpe F.N. and Nwanjoku F.N. (2013). Distribution and speciation of heavy metals in crude oil contaminated soils from Niger Delta, Nigeria. World Environment, 3 (1), 18-28
Iwegbue C.M.A. (2011). Assessment of heavy metal speciation in soils impacted with crude oil in Niger Delta, Nigeria. Chemical Speciation and Bioavailability, 23 (1), 7-15

Iyaka Y.A. and Kakulu S.E. (2009).Copper and zinc contents in urban agricultural soils of Niger State, Nigeria. African research review. An International Multi-disciplinary Journal, Ethiopia, 3 (3), 23-33

Kabata-Pendias A. (2011). Trace Elements in Soils and Plants ( ${ }^{\text {th }}$ ed.). CRC Press, Taylor and Francis Group, Boca Raton, USA. Pp 534

Kabata-Pendias A. and Pendias H. (2001). Trace Elements in Soils and Plants ( $3^{\text {rd }}$ ed.). CRC Press, Boca Raton, Florida, 413 pp

Koka J.K., Dodoo D.K., Kamb-Dorka J. and Kwakye P.K. (2011). Analysis of water soluble copper residue in the topsoils of some cocoa growing areas of the central region of Ghana. Pelagia Research Library. Der Chemica Sinica, 2 (2), 77-83

Lagomarsino, A. Marabottini, R. Grego, S. and Stazi, S.R. (2010). Copper distribution among physical and chemical fractions in a former vineyard soil. Agrochimica, Vol. LIV - N. 3. pp. 12

Mbila M.O., Thompson M.I., Mbagwu J.S.C. and Laired D.A. (2001). Distribution and movement of sludgederived trace metals in selected Nigerian soils. Journal of Environmental Quality, 30, 1667-1674

Melo Jr. G., Carvalho F.B. and Nogueira M.L.S. (2006). Baseline levels for selected elements in soils under semi-arid condition, Northeast of Brazil. Geophys. Res. Abstracts, EGU: 07331

Mustapha S., Voncir N. Umar S. and Abdulahamid N.A. (2011). Status and distribution of some available micronutrients in haplic usterts of Akko Local Government Area, Gombe State, Nigeria. International Journal of Soil Science, 6, 267-274

Nelson.D.W. and Sommers, L.E. (1982). Phosphorus. In: Page A.L., Miller R.H. and Keeney D.R. (Eds). Methods of Soil Analysis, Part 2. Amer. Soc. Agron. Madison, Wisconsin. pp. 539 -579

Nwagbara M.O. and Ibe O.K. (2015). Climate change and soil conditions in the tropical rainforest of Southeastern Nigeria. Journal of Geography and Earth Sciences, 3 (1), 99-106

Obalum S.E. and Chibuike G.U. (2017). Air-drying effect on soil reaction and phosphorus extractability from upland-lowland soils as related to their colloidal stability. Applied Ecology and Environmental Research, 15 (1), 525-540

Okoli N.H., Uzoho B.U., Onweremadu E.U., Nkwopara U.N. and Irokwe I. F. (2016). Zinc fractionation of soils of selected parent materials and their relationships with some soil properties. Malaysian Journal of Soil Science, 20, 49-66

Olson, S.R. and Sommers, L.E. (1982). Phosphorus. In: Page A.L., Miller R.H. and Keeney D.R. (Eds.) Part 2. Methods of Soil Analysis, Amer. Soc. Agron. Madison, Wisconsin. Pp. 403-430

Onweremadu E.U., Akamigbo F.O.R. and Igwe C.A. (2007b). Physical shrinkage relationship in soils of dissimilar lithologies in Central Southeastern Nigeria. Journal of Applied Science, 7, 2495 - 2499

Onweremadu E.U., Eshett E.T. and Osuji G. (2007a). Temporal variability of selected heavy metals in automobile soils. Int. J. Environ. Sci. Tech., 4 (1), $35-41$ 
Onweremadu E.U., Okon M.A., Ihem E.E., Okuwa J., Udoh B.T. and Imadojemu P. (2011). Soil exchangeable calcium mapping in Central Southeastern Nigeria using geographic information systems. Nigeria Journal of Agriculture, Food and Environment, 7 (2), 24-29

Onweremadu E.U. and Peter K.D. (2016). Pedogenesis of soils of two tropical microclimates in Owerri area South-east Nigeria. International Journal of Soil Science, 11(1), 14-18

Orajaka S.O. (1975). Geology In: Ofomata G.E.K. (Eds.) pp. 5-7. Nigeria in Maps: Eastern States. Ethiopia Publishers: Benin City, Nigeria

Oviasogie P.O., Aghimien A.E. and Ndiokwere C.L. (2011). Fractionation and bioaccumulation of copper and zinc in wetland soils of the Niger Delta determined by the oil palm. Chemical Speciation and Bioavailability, 23 (2), 95-105

Ramzan S., Bhat A.M., Kirmani N.A. and Rasool R. (2014). Fraction of zinc and their association with soil properties in soils of Kashmir Himalayas. International Invention Journal of Agriculture and Soil Science, 2 (8), 132-142

Rieuwerts J.S., Ashmore M.R., Farago M.E. and Thornton I. (2006). The influence of soil characteristics on the extractability of $\mathrm{Cd}, \mathrm{Pb}$ and $\mathrm{Zn}$ in upland and moorland soils. Science of Total Environment, 366, 864-875

Salbu B., Krekling T. and Oughton D.H. (1998). Characterization of radioactive articles in the environment. Analyst, 123, 843-849

Singh S.S. (2011). Soil Fertility and Nutrient Management. Kalyyani Publishers, New Delhi, India (Ed. 3). pp. 259
Thomas G.W. (1982). Exchangeable bases. In: Page A.L., Miller R.H. and Keeney D.R. (Eds.) Part 2. Methods of Soil Analysis. Amer. Soc. Agron. Madison, Wisconsin 159-165

Thomas G.W. (1996). Soil pH and soil acidity. In: Sparks D.L, Page A.L., Helmke P.A., Loeppert R.H., Soltanpour P.N., Tabatabai M.A., Johnson C.T. and Summer M.E. (Eds.). Methods of Soil Analysis, Part 3. Chemical Methods. Soil Science Society of America, Inc, and American Society of Agronomy, Maidson, WI.USA. Pp475-490

Udom B.E., Mbagwu J.S.C., Adesodun J. K. and Agbim N.N. (2004). Distribution of $\mathrm{Zn}, \mathrm{Cd}, \mathrm{Cu}$ and $\mathrm{Pb}$ in a tropical Ultisol after long term disposal of sewage sludge. Environment. International, 30, 467-470

Uzoho B.U., Ekpe I.I., Ahukaemere C.M., Ndukwu B.N., Okoli N.H., Osisi F.A. and Chris-Emenyonu C.M. (2014). Nitrogen status of soils of selected land uses of two cropping systems in the humid tropical rainforest, Southeastern Nigeria. Advances in Life Science and Technology, 25, 2224-7181

Verma V.K., Setia R.K., Sharma P.K., Singh C. and Ashok K. (2005). Pedospheric variations in distribution of DTPA-extractable micronutrients in soils developed on different physiographic units in Central parts of Punjab India. International Journal of Agriculture and Biology, 7, 243-246

Yu S., He Z.L., Huang C.Y., Chen G.C. and Calvert D.V. (2004). Copper fractionation and extractability in two contaminated variable charge soils. Geoderma, 123, $163-175$ 